\title{
The Effect of Professionalism on Education and Training in the Performance of Teacher in Junior High School of Ulak
}

\author{
Masning $^{1 *}$, Bukman Lian ${ }^{1}$, Alhadi Yan Putra ${ }^{1}$ \\ ${ }^{1}$ Universitas PGRI Palembang, Indonesia \\ "Corresponding author. Email: spdmasning@gmail.com
}

\begin{abstract}
Teachers' teaching skills and abilities have not been fully utilized, particularly when it comes to using electronic media to deliver lessons to students as a learning method that is appealing to students. There are few opportunities and costs for including teachers in education and training. The following hypotheses are tested in this study: 1) professionalism has an impact on teacher's success in the district of Cempaka OKU Timur; 2) education and preparation have an impact on teacher's performance in the district of Cempaka OKU Timur; and 3) professionalism, education and training together have an influence on the performance of elementary education. Data is gathered through observation, interviews, and questionnaires. The correlation analysis of the $\mathrm{t}$ test and the $\mathrm{F}$ test was performed. The findings of the data analysis revealed Effect of professionalism on teacher success in the district of Cempaka OKU Timur in primary schools. The output of elementary school teachers in the Timur district of Cempaka OKU was affected by education and training. Cempaka OKU Timur District Professionalism, education and training all affected the success of primary school teachers.
\end{abstract}

Keywords: Professionalism, Education, Training, Performance

\section{INTRODUCTION}

Education is a purposeful attempt to build human capital capacity by providing guidance, teaching, and training activities in preparation for their future role. Almost all countries place education as an important and main variable that provides the largest contribution to improving the quality of human resources. Increasing human resources will be successful if it is supported by good quality education. According to Wahyudi [1] education quality is based on a range of main influences, including teachers, school administrators, school facilities and infrastructure, and curriculum aligned with scientific advancements. The teacher is at the centre of all of these factors because he or she is directly responsible for the learning process.

Educational institutions and school directors strive to strengthen the professionalism of teachers, through several programs such as: upgrading, training, career promotion, and welfare. Professional teachers have a big influence in education so that they can produce quality educational outputs. In order to realize a professional teacher, it can be supported by participation in education and training, as well as teaching experience, which has been identified as an important influencing factor. It is hoped that the education and training that teachers participate in can develop teacher personality, develop careers, become more effective teachers and make teachers more professional. After passing the competency test in teacher education and professional training activities, teachers receive professional legalization recognition in the form of an educator certificate. Murwati [2] contends that participating in teacher education and professional development activities, teachers will get a lot of new knowledge that is useful for increasing their abilities or competencies in classroom learning.

Improving the quality of education in primary schools is heavily reliant on teacher professionalism. So, among all the components in the elementary school learning system, one determines the quality of learning the most: the teacher [3]. Based on Dahlan [4], teachers are also obliged to improve their professionalism. However, the heavy burden on teachers Due to the growing number of students and the heavier responsibility of meeting their everyday needs, as well as the rapid development of science and technology, have caused these obligations to not be fulfilled properly and completely.

To become a professional teacher really depends on the expertise and level of education they take, because the teaching position is one of the professional positions. Professional refers to a job or position that 
demands expertise, responsibility and professional loyalty. A profession in theory cannot be done by just anyone who is not trained or prepared for it. Regulation No. 16 of 2007 of the Minister of National Education, there are four competency standards for elementary school class teachers, namely pedagogical, personal, social, and professional competence [5]. If the teacher masters the four competencies, it can be said that a professional teacher with national standard.

Teachers are persons with unique skills and knowhow in the field of teacher education who enjoy the full exercise of their duties and functions as teachers. Teacher education qualifications are in accordance with the minimum prerequisites determined by the requirements of a professional teacher. According to Teacher and Lecturer Law No. 14 of 2005, a professional is a job or activity performed by an individual who becomes a livelihood source and requires knowledge, skills or qualifications which meet quality standards or standards and requires professional training [6].

Education is the leading indicator of a nation's development [7]. School is an extremely significant human need because education has an obligation to build and advance human resources for the country [8]. Professionalism can no longer be deferred. In the age of globalization, the growing rivalry is harder, the professionalism of an instructor must be increased [9]. The work of academic supervision is one effort towards improving professionalism and assessing teachers' competence, so managers must be qualified to undertake academic supervision [10].

Based on data from the Cempaka Subdistrict Education Management Unit, there are 52 class teachers with the status of Civil Servants spread across 3 elementary schools in Ulak Baru. The teachers come from different educational backgrounds, including teacher training school, Diploma II, and Bachelor graduates. Each has different training frequencies, and has different tenure / teaching experiences. Based on these data, the authors want to know the extent of these differences and their effect on teacher professionalism.

Starting from the description above, the writer tries to examine the problems that are thought to be related to the performance of the Ulak Baru Elementary School, namely "The Effect of Professionalism on Education and Training in The Performance of Teacher in Junior High School of Ulak".

\section{METHODS}

The research was conducted at Ulak Baru Elementary School. The authors used quantitative data in this study, which is research that requires the use of numbers from data collection to data interpretation and the presentation of the results. Quantitative research is a type of research in which the specifications are systematic, planned, and clearly structured from the beginning of the research design to the end.

According to Sugiono [12], population is "a generalization area consisting of objects or subjects with certain quantities and characteristics that researchers are expected to study and then draw conclusions from." This study's population consisted of all elementary school teachers in Ulak Baru, which had three elementary schools, namely elementary school 1 Ulak Baru, which had 14 teachers, elementary school 01 Gunung Jati, which had 13 teachers, and elementary school 02 Gunung Jati, which had 13 teachers, for a total of 40 teachers.

The sample is a subset or representative of the population being studied (Arikunto, 2010). If the sample size is less than 100 , it is preferable to take all of them so that the research is population research. If the subject is larger, it can be taken at a rate of 20-25\% [13].

In this study, all of the population was taken as the research sample, namely 40 people, while 20 people were used for testing the research instrument.

In this study, two types of data are required: primary and secondary information. The primary data source is derived from empirical research findings obtained by distributing questionnaires to students at Ulak Baru Elementary School. Meanwhile, secondary data is obtained from monthly and annual reports, staffing data, and office documentation.

\section{RESULTS AND DISCUSSION}

\section{1) Hypothesis Testing Professionalism $\left(\mathrm{X}_{1}\right)$ on Performance (Y)}

In the form of the regression equation $\mathrm{Y}=24.247+$ $0.746 \mathrm{X} 1$, the design for the influence of the school community and teacher performance is expressed. The significant level of the linear regression is seen in the table below.

Table 1.

$\mathrm{X}_{1}$ Against $\mathrm{Y}$

\begin{tabular}{|c|c|c|c|c|c|c|}
\hline \multirow{2}{*}{\multicolumn{2}{|c|}{ Model }} & \multicolumn{2}{|c|}{$\begin{array}{c}\text { Unstandardized } \\
\text { Coefficients }\end{array}$} & \multirow{2}{*}{$\begin{array}{c}\text { Standardized } \\
\text { Coefficients }\end{array}$} & \multirow[t]{2}{*}{$\mathrm{t}$} & \multirow[t]{2}{*}{ Sig. } \\
\hline & & B & $\begin{array}{l}\text { Std. } \\
\text { Error }\end{array}$ & & & \\
\hline \multirow[t]{2}{*}{1} & (Constant) & 56.534 & 14.294 & & 3.955 & 0.000 \\
\hline & Professionalism & 101 & .179 & 0.91 & 3.566 & 0.001 \\
\hline
\end{tabular}

a. Dependent Variable: Teacher Performance 
The $\mathrm{t}$ value in the table above is 3,566, With a 0,000-sig standard. Because the sig value is less than 0.05 , the conclusion that professionalism has an effect on Ulak Baru's success is appropriate. This means that Ulak Baru Elementary School teachers' performance is influenced by their professionalism.

\section{2) Hypothesis Testing on Education and Training} $\left(X_{2}\right)$ on Performance $(Y)$

Table 2. X2 Against Y

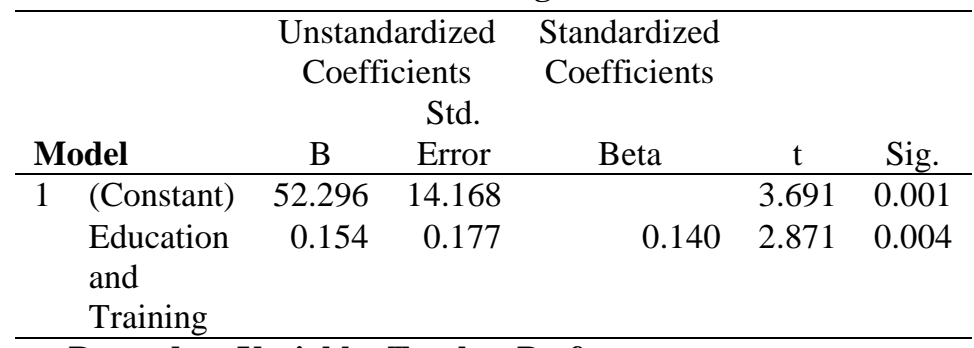

a. Dependent Variable: Teacher Performance

The $\mathrm{t}$ value is 2,871 , with a significance level of 0.004 as set out in the above figure. The assumption that learning and preparation influence success of Ulak Baru Elementary School teachers is accepted because the sig value is less than 0.05 . This means that the performance of Ulak Baru Elementary School teachers is influenced by education and training.

3) Hypothesis Testing of Professionalism (X1) and Education and Training (X2) on Performance (Y)

Table 3. $X_{1}$ and $X_{2}$ Against $Y$

\begin{tabular}{|c|c|c|c|c|c|}
\hline Model & $\begin{array}{l}\text { Sum of } \\
\text { Squares }\end{array}$ & df & $\begin{array}{c}\text { Mean } \\
\text { Square }\end{array}$ & $\mathrm{F}$ & Sig. \\
\hline 1 Regression & 52.816 & 2 & 26.408 & 14.480 & $.000^{\mathrm{a}}$ \\
\hline Residual & 2034.784 & 37 & 54.994 & & \\
\hline Total & 2087.600 & 39 & & & \\
\hline
\end{tabular}

a. Dependent Variable: Teacher Performance
b. Predictors: (Constant), Professionalism, Education and
Training

Training

\section{CONCLUSION}

Based on previous research and discussion, either through descriptive statistical analysis or inferential statistical analysis, the following conclusions can be drawn from this study: professionalism has an Impact on the performance of Ulak Baru Teachers, Education and Training has an impact on the performance of the teachers of Ulak Baru Elementary School and together the performance of Ulak Baru Elementary School teachers is influenced by professionalism and education and training.

For researchers to follow up further on the results of this study by developing independent variables that can improve the performance of the Ulak Baru Elementary School. This needs to be done because other variables still have an effect on teacher success besides Professionalism and Education and Training because only $84.4 \%$ of Teacher Performance is determined by Professionalism and Education and Training, meaning $15.6 \%$ is determined by factors outside of Professionalism and Education and Training such as work discipline, job satisfaction and others.

\section{ACKNOWLEDGMENT}

Our deepest gratitude goes to Teachers in SD Negeri Cempaka OKU Timur, Chancellor of Palembang PGRI University, Director of the Postgraduate Program of PGRI Palembang University and the Education Management Study Program of PGRI Palembang University, who have supported us in doing this extraordinary thing. This project is funded independently. We also want to thank our Education Management friends who helped us a lot in a short time frame to complete this project. 


\section{REFERENCES}

[1] Wahyudi. (2010). Standar Profesionalisme Guru [Teacher Professionalism Standards]. Jurnal Pendidikan dan Sosiologi dan Humaniora. Volume I No. 2.

[2] Murwati, H. (2013). Pengaruh Sertifikasi Profesi Guru Terhadap Motivasi Kerja Dan Kinerja Guru Di Smk Negeri Se-Surakarta [The Effect of Teacher Professional Certification on Work Motivation and Teacher Performance in Public High Schools in Surakarta]. Jurnal Pendidikan Bisnis dan Ekonomi. Volume I No. 1.

[3] Bafadal, I. (2010). Peningkatan Profesionalisme Guru [Increasing Teacher Professionalism]. Jakarta: PT. Bumi Aksara.

[4] Dahlan, T. (2003). Pedoman Manajemen Berbasis Madrasah [Madrasah Based Management Guidelines]. Jakarta: Departemen Agama RI.

[5] Ambar. (2009). Manajemen Sumber Daya Manusia [Human Resource Management]. Yogyakarta: Graha Ilmu.

[6] Fahrurrozi. (2005) Pengaruh Gaya kepemimpinan dan Pelatihan tehadap kinerja pegawai PT Pusri [The influence of leadership style and training on the performance of PT Pusri Palembang employees]. Palembang: Tesis MM UTP.

[7] Asvio, N., Yamin, M., \& Risnita. (2019). Influence of Leadership Style, Emotional Intelligence and Job Satisfaction toward Organizational Commitment (Survey at SMA Muhammadiyah South Sumatera). International Journal of Scientific \& Technology Research 8 (8).

[8] Handayani, D. O., Kristiawan, M., \& Destiniar. (2020). Education and Training for Strengthening Principal to Effective Schools. International Journal of Progressive Sciences and Technologies (IJPSAT), 22(1), 321-326.

[9] Kristiawan, M., \& Rahmat, N. (2018). Peningkatan Profesionalisme Guru Melalui Inovasi Pembelajaran. Jurnal Iqra': Kajian Ilmu Pendidikan, 3(2), 373-390. https://doi.org/10.25217/ji.v3i2.348

[10] Khasanah, U., Kristiawan, M., \& Tobari. (2019). The Implementation of Principals' Academic Supervision in Improving Teachers' Professionalism in the State Primary Schools. International Journal of Scientific \& Technology Research, 8(8).

[11] Sugiono. (2019). Metode Penelitian Bisnis [Business Research Methods]. Bandung: CV. Alfabeta.

[12] Arikunto, S. (2002). Metode Penelitian dan Statistika [Research Methods and Statistics]. Jakarta: Dunia Pustaka Jaya. 